\title{
Hugo Grotius's Views on Consent, Contract and the Christian Commonwealth - Introductory Remarks
}

\author{
Wim Decock \\ KU Leuven/ULiège, Belgium \\ wim.decock@kuleuven.be
}

In textbooks on international law, Grotius's De iure belli ac pacis is frequently cited as proof of the Protestant origins of international law. Reaching back to Enlightenment commentaries on Grotius, this claim was reinforced at the threshold of the twentieth century and has prospered ever since, thanks to Hamilton Vreeland Jr.'s influential biography designating Grotius as the 'father of the modern science of international law'. ${ }^{1}$ Not unlike Weber's account of the 'Protestant origins of capitalism', this claim has developed into a grand narrative about the 'Protestant origins of modern international law' that has become popular not only among jurists, but also historians, philosophers and political scientists. Yet, this claim must be nuanced, ${ }^{2}$ and against the background of growing confessional rivalry between Protestants and Catholics at the turn of the twentieth century, it has also been subject to criticism. Catholic jurists trying to vindicate the importance of their own tradition have developed a counter-narrative. James Brown Scott, the American 'dean of international law', played a crucial role in this endeavor. He emphasized the fundamental contribution to the rise of modern natural and international law by Catholic teólogos-juristas, notably Francisco de Vitoria and Francisco Suárez. ${ }^{3}$ Scott's endeavor, however, was born not out of mere academic

1 H. Vreeland Jr., Hugo Grotius: The Father of the Modern Science of International Law (New York: Oxford University Press, 1917).

2 M. Becker, Kriegsrecht im frühneuzeitlichen Protestantismus. Eine Untersuchung zum Beitrag lutherischer und reformierter Theologen, Juristen und anderer Gelehrter zur Kriegsrechtsliteratur im 16. und 17. Jahrhundert (Tübingen: Mohr Siebeck, 2017).

3 Conservative forces in the Spanish-speaking world had an obvious interest in promoting this view, see I. de la Rasilla del Moral, In the Shadow of Vitoria: A History of International Law in Spain (1770-1953) (Leiden/Boston: Brill/Nijhoff, 2018), pp. 154f. See also W. Decock and C. Birr, Recht und Moral in der Scholastik der Frühen Neuzeit 1500-1750 (Berlin: De Gruyter, 2016), pp. $77-78$. 
interests. As Mark Somos and Joshua Smeltzer show, Scott's elevation of the School of Salamanca served the purpose of promoting US exceptionalism. ${ }^{4}$ Incidentally, other researchers, indifferent to identity politics along either religious or nationalist lines, have developed a third master narrative. It has gathered momentum since the second half of the twentieth century and presents Grotius as a kind of modern humanist, who played a paramount role in 'secularizing' law. Often starting from the 'etiamsi daremus-postulate', those narratives emphasize Grotius's role in emancipating law from its religious moorings.

While there is some truth in each of these conflicting storylines, they have brought to bear distinctly modern preoccupations on the life and work of a sui generis thinker who died in Rostock on August 28, 1645 - after five months of erratic travelling across land and sea, barely surviving a shipwreck in the Baltic and without finding spiritual refuge in any clear-cut orthodoxy. Grotius continues to defy modern categories. He was a prominent jurist, astute diplomat and independent Christian thinker foremostly engaged in addressing the challenges of his own time, which entailed, certainly in his youth, defending the global commercial interests of the nascent Dutch republic. ${ }^{5}$ Moreover, it is appropriate to recall, as Jan Waszink does in a recent piece, that the first biographers of Grotius cared little about Grotius's place in the genealogy of (international) law. ${ }^{6}$ They debated his theological views, instead. Grotius, after all, did not only write juridical works, but also major theological treatises. ${ }^{7} \mathrm{He}$ was a theologian as much as a lawyer. ${ }^{8}$ Waszink's subtle, short but important wake-up call can be read as an invitation to try to go beyond traditional narratives and concentrate on what mattered to Grotius himself. As Henk Nellen's groundbreaking biography of Hugo Grotius shows, the concerns of the jurist-theologian from Delft related as much to the re-unification of the Christian Churches as to the legal framework for dealing with war. In other words, he cherished Meletius

4 M. Somos and J. Smeltzer, 'Vitoria, Suárez and Grotius: James Brown Scott's Enduring Revival', infra.

5 M. van Ittersum, Profit and Principle. Hugo Grotius, Natural Rights Theories and the Rise of Dutch Power in the East Indies, 1595-1615 (Leiden: Brill, 2006).

6 J. Waszink, 'Review: H.J.M. Nellen, Hugo Grotius, A Lifelong Struggle for Peace in Church and State, 1583-1645', History of European Ideas 46 (2020), 209-211, at p. $210 n 2$.

7 J.W. Oosterhuis, 'Hugo Grotius', in: Great Christian Jurists in the Low Countries, ed. by W. Decock and J.W. Oosterhuis (Cambridge: Cambridge University Press, forthcoming).

8 J.E. Nijman, 'Grotius' Imago Dei Anthropology: Grounding Ius Naturae et Gentium', in: International Law and Religion: Historical and Contemporary Perspectives, ed. by M. Koskenniemi, M. García-Salmones Rovira and P. Amorosa (Oxford: Oxford University Press, 2017), pp. 87110. Incidentally, similar observations apply to some of the major authors that influenced Grotius's work, viz. the teólogos-juristas of the School of Salamanca. 
(1611) as much as De iure belliac pacis (1625/1631). A Christian humanist, Grotius sought to promote concordia in general, and reconciliation between Christian communities and nations, in particular. Notions of faith, trust, concord, consent, promise and contract played a major role in that struggle for concord. They have captured Grotius's mind early on, already figuring prominently in Parallelon rerumpublicarum (1602), as Hans Blom has pointed out. ${ }^{9}$

For reasons of scope and feasibility, the aim of the papers collected in this Dossier is not primarily to tease out the political implications of Grotius's musings on contract and consent. This is not to deny that such an approach can yield interesting insights. Quite the contrary, a paper published in the previous Grotiana issue explores the potential of such an approach precisely with regards to notions of promise, consent and contract. ${ }^{10}$ Moreover, Daniel Lee has managed to shed new light on Grotius's political theory by showing how the application of private law notions of property and usufruct allowed him to conceptualize the relationship between popular liberty and princely sovereignty in a novel way. ${ }^{11}$ Consequently, Grotius's transposition of private law vocabulary - heavily drawing on Roman law in its medieval and early modern form - into categories of political thought is a topic that would deserve careful treatment in a special issue of its own. However, there is an urgent need for examination of the juridical-historical background of private law concepts employed by Grotius, in the first place, and that is what many of the articles in this Dossier try to offer. They are the fruit of a colloquium organized in Louvain on 15 November 2018 by the Grotiana Foundation and KU Leuven's Department of Roman Law and Legal History. Its objective was to gather international scholars from different institutional backgrounds to reflect upon Grotius's doctrine of consent and contract from the point of view of their expertise in the ius commune tradition, the development of moral theology and natural law in the Spanish, German and Scandinavian areas, and the (instrumental) use of Grotius's thought in recent times.

A fine example of Grotius's paramount concern about strengthening the cohesion between Christians of different Churches is offered in his teachings on consent to alliances with infidels - the topic of Orazio Condorelli's article

H. Blom, 'Hugo Grotius on Trust, Its Causes and Effects', in: Trust and Happiness in the History of European Political Thought, ed. by L. Kontler and M. Somos (Leiden/Boston: Brill, 2018), pp. $76-98$ (77).

10 L. Ramelet, 'Political Consent, Promissory Fidelity and Rights Transfers in Grotius', Grotiana 40 (2019), 123-145.

11 D. Lee, 'Popular Liberty, Princely Government, and the Roman Law in Hugo Grotius's "De iure belli ac pacis"', Journal of the History of Ideas 72 (2011), 371-92. 
which opens this Dossier. ${ }^{12}$ Condorelli's analysis reveals that Grotius's discussion of this old problem is, ultimately, more about tightening the bond between Christian nations than fostering the validity of treaties concluded with infidels. From the point of view of natural law, Grotius does not doubt the binding character of the so-called impium fedus, since natural law applies to all human beings regardless of their religious convictions. But he also addresses the issue from the point of view of Biblical norms - divine positive law eventually arriving at the conclusion, similar to that of Thomas Aquinas, that alliances with infidels are permissible in principle, but can be forbidden as a precautionary measure, for instance if such alliances are indirectly harmful to Christian communities. Moreover, Grotius's discussion then shifts into an exhortation towards Christians to unite and cooperate to defend themselves against the menace of non-Christian people. Grotius's inclinations towards irenicism, then, should not be understood in a twentieth-century, humanist sense. Of course he did not promote aggressive submission of the Ottomans to the Christian faith, nor did he recommend aggressive wars. But there were limits to Grotius's tolerance of religious diversity, dictated by his loyalty to the Christian faith. He adopted a suspicious attitude towards the Ottomans, much like Erasmus a century before him. ${ }^{13}$ Their advocacy for religious tolerance was primarily oriented towards the peaceful coexistence of various Churches within the Christian commonwealth.

Besides shedding fresh light on Grotius's preoccupation with Christian unity, Condorelli's article shows that Grotius's contract law cannot be severed from its intellectual-historical context. Grotius entered into a permanent dialogue with late medieval and early modern interpreters of Roman law, canon law and the Holy Scriptures. Only if we take this dialogue with the legal and theological traditions seriously, can we truly understand the direction his arguments take. While Grotius was sui generis in the way he combined all learned traditions, it is imperative to acknowledge the permanent conversation that he engaged in with authors belonging to the ius commune tradition. From the Renaissance of Justinian's Roman law at universities like Bologna in the late eleventh century onwards until the end of the Enlightenment period, Roman law, combined with canon law, had in fact been the basis of teaching and research at Law Faculties in Europe. ${ }^{14}$ As a result, Roman law, through the lens of its late

12 O. Condorelli, 'Grotius's Doctrine of Alliances with Infidels and the Idea of Respublica Christiana', infra.

13 N. Malcolm, Useful Enemies: Islam and the Ottoman Empire in Western Political Thought, 1450-1750 (Oxford: Oxford University Press, 2019), p. 32.

14 M. Bellomo, The Common Legal Past of Europe, 1000-1800 (Washington DC: Catholic University of America Press, 1995). 
medieval and early modern interpretations, was 'a kind of legal supermarket', to use Peter Stein's apt phrase, ${ }^{15}$ in which intellectuals and policymakers 'found what they needed at the time.' The training of future administrators, leaders and lawyers relied, in essence, on transmitting the vocabulary and grammar of Roman law and canon law - the tradition of 'both laws' (utrumque ius) that was shared across European universities (ius commune). Along with prior training in 'Letters' (artes), which included Aristotelian logic and Greco-Roman rhetoric, studying Roman law formed the backbone of legal, and hence, executive education until the end of the eighteenth century. While many of the ius commune authors are now suffering from scholarly neglect, their works should be revisited if we want to assess Grotius's place in the history of ideas. ${ }^{16}$

As Giovanni Chiodi lays out in great detail, Grotius drew directly on the ius commune tradition and early modern scholastic theology in developing influential concepts such as the non-binding character of unilateral promises (pollicitationes) ${ }^{17}$ Grotius's endorsement of the principle of offer and acceptance $(I B P 2,11,14)$ which, in fact, is a transplant from Leonardus Lessius, is still being considered authoritative by modern jurists. ${ }^{18}$ Without recognizing the diverging opinions within the civil law and canon law traditions on the binding nature of unilateral promises, it is difficult, if not impossible, to see what was at stake when Grotius tried to solve that old question by adopting Leonardus Lessius's reasoning. ${ }^{19}$ Paying attention to hitherto neglected primary source material, Chiodi brings back to life the many jurists and theologians that Grotius was engaging with. Mostly cut off from explicit references to its origins in ius commune debates and early modern scholastic authors, Grotius's formulation of the doctrine of offer and acceptance lived on in different contexts. In the Swedish-Finnish and Danish-Norwegian regions, where modern

15 P. Stein, Roman Law in European History (Cambridge: Cambridge University Press, 1999), p. 2.

16 A Bio-Bibliographical Guide to Medieval and Early Modern Jurists, based on Kenneth Pennington's seminal work, is currently being developed under the auspices of the Ames Foundation, see http://amesfoundation.law.harvard.edu/BioBibCanonists/HomePage biobib2.php (last accessed 17 April 2020). For jurists from the late medieval period, many of which figure prominently in Grotius's work, see also H. Lange, Römisches Recht im Mittelalter: Die Glossatoren (Munich: C.H. Beck, 1997), and H. Lange and M. Kriechbaum, Römisches Recht im Mittelalter: Die Kommentatoren (Munich: C.H. Beck, 2007).

17 G. Chiodi, 'The Binding Force of Unilateral Promises in the Ius Commune before Grotius', infra.

18 See Gregor Christandl's commentaries on general provisions regarding the formation of contracts, in: Commentaries on European Contract Laws, ed. by N. Jansen - R. Zimmermann (Oxford: Oxford University Press, 2018).

19 W. Decock, Theologians and Contract Law: The Moral Transformation of the Ius Commune (ca.1500-1650) (Leiden/Boston: Brill/Nijhoff, 2012), pp. 178-91 and 208-12. 
natural law theories found fertile ground, the idea that binding promises required acceptance to become enforceable was widespread. Although explicit references to Grotius are often lacking in Scandinavian legal literature, Sören Koch nevertheless finds indirect evidence of jurists' and administrators' familiarity with De iure belli ac pacis in the field of contract law. ${ }^{20}$ For example, on the private book market Grotius's works circulated as widely as Samuel von Pufendorf's natural law treatises. Incidentally, lawyers who had studied abroad, such as the seventeenth-century Danish lawyer and polymath Peder Hansen Resen, or the eighteenth-century Swedish jurist David Nehrman Ehrenstråle, did quote Grotius, next to early modern scholastic authors such as Molina.

Combined with Paolo Astorri's contribution on the reception of Grotius's ideas on consent and contract in Lutheran theology, Koch's article makes one wonder whether (Lutheran) theologians, even more so than lawyers, contributed to spreading Hugo Grotius's ideas on consent and contract in the Lutheran North. As Koch points out, as late as 1729 Ludvig Holberg complained that the university of Copenhagen would exclusively educate theologians, not jurists. As a matter of fact, Astorri indicates in his contribution that Lutheran theologians in the German area were eager to study Hugo Grotius as an alternative to Pufendorf, whom they considered as threatening in many regards. ${ }^{21}$ Major Lutheran theologians such as Johann Adam Osiander, who taught at Tübingen in the second half of the seventeenth century and counted many Swedish youngsters among his students, engaged intensely with Grotius's De iure belli ac pacis. Moreover, Lutheran theologians thoroughly engaged with contract law, in particular, recycling ideas and concepts from the Roman law, the early-modern scholastic tradition and Grotius, but integrating them into a Biblical framework, especially the Eighth Commandment prohibiting false testimony. ${ }^{22}$ Astorri also considers the contested nature of the reception of Grotius's ideas on promises and contracts in the work of jurists such as Johann von Felden, who taught in Helmstedt. In his Annotata in Hugonem Grotium de iure belli ac pacis, Felden basically considered Grotius as unfaithful to pristine Roman law. This accusation was refuted by the Dutch jurist Theodor Graswinckel, Grotius's cousin. The debate between Felden and Graswinckel provides testimony to the polemical nature of Grotius's reception in the seventeenth century - a polemical reception which was due, not in the least, to Grotius's indebtedness to medieval and early modern traditions in law and theology.

20 S. Koch, 'Grotius's Impact on the Scandinavian Theory of Contract Law', infra.

21 P. Astorri, 'Grotius's Contract Theory in the Works of his German Commentators: First Explorations', infra.

22 P. Astorri, Lutheran Theology and Contract Law in Early Modern Germany (ca. 1520-1720) (Paderborn: Schöningh/Brill, 2019), p. 186. 
These controversies also attest to the fundamentally 'pluralistic' nature of natural law jurisprudence in the early modern period. ${ }^{23}$

Even if it was not the primary aim of each and every paper in this Dossier to discuss questions regarding the originality of Grotius's thought, they can be read as contributing to the protracted debate on whether Grotius merely continued earlier traditions in law and theology or whether he was the harbinger of a new paradigm. It is true that specialists in the history of early modern natural law, such as Knud Haakonssen, warn 'those whose idea of natural law has been formed by scholasticism' to see too much continuity between 'scholastic natural law' and early modern, Protestant accounts of natural law. ${ }^{24}$ As Richard Tuck once noted, it is not to be expected, indeed, 'that in the course of such a long history the meanings of even central terms should be at all stable. ${ }^{\prime 25}$ Especially if one considers the strongly diverging theories of such scholars as Hobbes, Pufendorf, Barbeyrac, Thomasius and Wolff, there are obvious reasons to pay attention to the great variations in the definitions of 'natural law' and, hence, pay heed to Haakonssen's admonishment. Yet, assessing Grotius's exact place in this long line of original thinkers remains an altogether different thing. ${ }^{26}$ In a contribution that recalls Peter Haggenmacher's and Dominik Recknagel's attempts at showing the profound continuity between Suárez's and Grotius's natural law theories, ${ }^{27}$ Sydney Penner reminds us of just how difficult it is to find arguments demonstrating that the caesura between 'old' and 'new' paradigms in natural law should be identified with Grotius. ${ }^{28}$ In that regard, it is easier to establish the difference between modern theories of consent in international law and Grotius's view of the role of consent in establishing the sources of international law, as Christoph Stumpf does in his

23 K. Haakonssen, 'Early Modern Natural Law Theories', in: The Cambridge Companion to Natural Law Jurisprudence, ed. by G. Duke and R.P. George (Cambridge: Cambridge University Press, 2017), pp. 76-102, at pp. 78-79.

24 Haakonssen, 'Early Modern Natural Law Theories', p. 76.

25 R. Tuck, Natural Rights Theories: Their Origin and Development (Cambridge: Cambridge University Press, 1979), p. 7, also cited in D. Lee, 'Richard Tuck, Natural Rights Theories', in: The Oxford Handbook of Classics in Contemporary Political Theory, ed. by J.T. Levy (Oxford: Oxford University Press, 2017), DOI: 10.1093/oxfordhb/9780198717133.013.40 (last consulted 17 April 2020).

26 M. Scattola, Das Naturrecht vor dem Naturrecht. Zur Geschichte des 'ius naturae' im 16. Jahrhundert (Tübingen: Max Niemeyer, 1999), pp. 215-18.

27 P. Haggenmacher, Grotius et la doctrine de la guerre juste (Paris: Presses Universitaires de France, 1983); D. Recknagel, Einheit des Denkens trotz konfessioneller Spaltung. Parallelen zwischen den Rechtslehren von Francisco Suárez und Hugo Grotius (Frankfurt am Main: Lang, 2010).

28 S. Penner, 'Making Use of the Testimonies: Suárez and Grotius on Natural Law', infra. 
contribution. ${ }^{29}$ For example, the positivistic premises of today's public international law see consent to international norms essentially as a foundation stone for their validity, while Grotius regards the consensual basis of universal norms as an a posteriori epistemological proof of their existence as natural laws. But, in practice, Stumpf argues, this almost comes down to the same thing.

In this author's view, the articles in this Dossier show that Grotius's work remains surprisingly rich in ideas both for historians and contemporary jurists. On that account, Grotius's thought also remains elusive. It contains elements so diverse that it is possible to see the jurist-theologian from Delft both as a traditionalist and an innovator. Even if questions of genealogy are not at the heart of the contributors' investigations, the papers by Chiodi, Condorelli and Penner substantiate the claim that recognizing Grotius's indebtedness to medieval Thomism, the ius commune and early modern scholastic traditions is necessary to reach full understanding of his ideas. As Brian Tierney once noticed, an expert in medieval canon law examining Grotius's De iure belli ac pacis cannot avoid feelings of 'déjà-vu' ${ }^{30}$ Specialists in early modern scholastic literature are undoubtedly struck by similar emotions. After all, the 'naturalization of the ius commune tradition' and the introduction of a 'legalistic ethics', often associated with Hugo Grotius, ${ }^{31}$ are the hallmark of early-modern scholastic writers such as Leonardus Lessius. Other papers in this Dossier, however, such as Paolo Astorri's and Sören Koch's contributions, highlight the crucial role which Grotius played as an authority among scholars who thought of themselves as renewing the paradigm of natural law, especially in Lutheran circles in Germany and the Nordic countries. It should be recalled, from a purely institutional point of view, that the first chairs in natural law used Grotius's De iure belli ac pacis as their reference text and that Grotius's influence on legal education and political practice was huge. To give just one example, one can learn from a brand-new research project conducted by Mark Somos that Andrew Elliot, a Harvard alumnus and preacher in Boston, drew on Grotius when justifying the American revolution in his sermons. ${ }^{32}$ Even today, as Christoph

29 C. Stumpf, 'Consent and the Ethics of International Law - Revising Grotius's System of States in a Secular Setting', infra.

30 B. Tierney, The Idea of Natural Rights. Studies on Natural Rights, Natural Law and Church Law, 1150-1625 (Atlanta: Scholars Press, 1997), p. 167.

31 B. Straumann, 'A Reply to my Critics. Adam Smith's Unfinished Grotius Business, Grotius's Novel Turn to Ancient Law, and the Genealogical Fallacy', Grotiana 38 (2017), 211-228, at p. 223 .

32 M. Somos, 'The Unseen History of International Law: A Census Bibliography of Hugo Grotius's De iure belli ac pacis', Grotiana 40 (2019), 173-179, at p. 177. 
Stumpf's paper shows, Grotius remains a popular authority among international lawyers and judges at international courts. ${ }^{33}$ The same does not hold true for the sources on which Grotius was drawing.

Upon reading the papers in this Dossier, we may conclude with Henk Nellen that Grotius cannot be seen as a radical innovator, but as an "homme de continuité", a traditionalist, who gathered elements from everywhere and grafted them onto a system of his own, where they soon bore new fruit'. ${ }^{34}$ The permeability of Grotius's thought to traditions as diverse as the classical rhetorical tradition, Aristotelianism, Stoicism, Tacitism, medieval Thomism, canon law, the mos italicus, the mos gallicus, the School of Salamanca, Arminian theology and Jesuit scholasticism does not detract from the extraordinary value and impact of his work. Yet, clearly, the transition to a rights-centered and systematic conception of law that is often associated with Grotius was anticipated in the works of early modern scholastics, especially in Lessius's De iustitia et iure, whom we know Grotius followed almost blindly, to the point of copying the same mistakes in source citations. ${ }^{35}$ Legal historians such as Franz Wieacker, Robert Feenstra, James Gordley, Jan Hallebeek, Bart Wauters and Joe Sampson have drawn sufficient attention to this. When it comes to the substance and technical aspects of Grotius's contract doctrine, in particular, Grotius has been shown to rely heavily on the Jesuit moral theologian Lessius. ${ }^{36}$ Already back in 1973, Feenstra warned scholars that Malte Diesselhorst had grossly underestimated the impact of Lessius on Grotius's contract law. ${ }^{37}$ As a matter of fact, for the sake of the stability of contractual relationships and trade, both Grotius and Lessius sought to promote, not the spreading of 'secularization' in the sense of atheism, but the 'secularization' of legal argument. ${ }^{38}$ On the basis of universal legal principles, based on rational nature, they wanted to protect

33 Stumpf, 'Consent and the Ethics of International Law', passim.

34 H. Nellen, A Lifelong Struggle for Peace in Church and State, 1583-1645, (Leiden/Boston, : Brill, 2014), p. 374.

35 R. Feenstra, 'L'influence de la scolastique espagnole sur Grotius en droit privé: quelques experiences dans des questions de fond et de forme, concernant notamment les doctrines de l'erreur et de l'enrichissement sans cause', in: La seconda scolastica nella formazione del diritto privato moderno, ed. by P. Grossi (Milan: Giuffrè, 1973), pp. 377-402, at pp. 382-86.

36 Decock, Theologians and Contract Law, pp. 208-12 (offer and acceptance), pp. 272-74 (mistake), pp. 321-24 (duress), pp. 494-96 (immoral agreements), pp. 598-601 (fairness).

37 Feenstra, 'L'influence de la scolastique espagnole sur Grotius en droit privé', p. 386.

38 M. Somos, Secularisation and the Leiden Circle (Leiden/Boston: Brill, 2011), pp. 383-438 pace Jan Machielsen, whose critical book review in The English Historical Review 128 (2013), 682-84, merits attention. 
individual rights beyond confessional strife. ${ }^{39}$ Importantly, they shared this central concern with other scholars from the Low Countries, centered not only in Leiden but also in Louvain. ${ }^{40}$ After all, they had gained first-hand experience, in the Lowlands, of the devastating effects of civil war fueled by religious zeal and absolutist leadership.

Grotius's dependency on authors such as Balthasar Ayala, Fernando Vázquez de Menchaca and Leonardus Lessius does not mean in any way, of course, that the development of the European legal tradition can be understood without reference to him. It was Grotius, not a Spanish natural lawyer, who became the textbook author commented upon by chairs of natural law in universities across the world. ${ }^{41}$ By the same token, neglecting the substantive value of classical sources from Antiquity in Grotius's work impairs our understanding of his unique political-juridical project and the systematic importance of notions such as appetitus societatis, fides and oikeiôsis. ${ }^{42}$ Stoic philosophy, in particular, has been shown by Hans Blom, Laurens Winkel, and Benjamin Straumann to have exerted a major influence on Grotius, just as it did on Justus Lipsius, an intimate friend of Grotius's father. Grotius was probably the first jurist to realize the enormous potential of understanding the notion of appetitus societatis against a Ciceronian background, even if he got the term from Vázquez de Menchaca. ${ }^{43}$ At the same time, Grotius read Aristotelian-Stoic ideas against the background of fundamental Judeo-Christian values. ${ }^{44}$ In addition, Ciceronian ethics was not exclusive to Grotius. It was at the heart of contemporary Jesuit pedagogy and moral theology, too. ${ }^{45}$ The mixing of sources from classical Antiquity, the patristic period, late medieval scholasticism and French legal

39 For further explanation, see the analysis of Martinus Becanus's and Leonardus Lessius's contribution to the 'naturalization' and 'secularization' of the legal sphere in my 'Trust Beyond Faith. Re-Thinking Contracts with Heretics and Excommunicates in Times of Religious War', Rivista Internazionale di Diritto Commune 27 (2016), 301-28 and Martin Becanus, On the Duty to Keep Faith with Heretics, transl. by I. Buhre; introd. by T. Dienst and C. Strohm (Grand Rapids: CLP Academic, 2019).

40 L. Waelkens, Amne adverso: Roman Legal Heritage in European Culture (Leuven: Leuven University Press, 2015), pp. 138-139.

41 K. Haakonssen, 'Enlightenment and the Ubiquity of Natural Law', in: Zeit in der Aufklärung, 13. Internationaler Kongress zur Erforschung des 18. Jahrhundert, (=Das achtzehnte Jahrhundert und Oesterreich 27 (2012), pp. 45-57), p. 47.

42 H. Blom, 'Sociability and Hugo Grotius', History of European Ideas 41 (2015), 589-604.

43 But the Spanish jurist is said to have used the term in an exclusively Aristotelian sense, see B. Straumann, Roman Law in the State of Nature. The Classical Foundations of Hugo Grotius' Natural Law (Cambridge: Cambridge University Press, 2015), pp. 90-91n24.

44 Nijman, 'Grotius' Imago Dei Anthropology', p. 89.

45 R. Maryks, Saint Cicero and the Jesuits. The Influence of the Liberal Arts on the Adoption of Moral Probabilism (Aldershot: Ashgate, 2008). 
humanism was already a distinguishing feature of Spanish jurists known and cited by Grotius such as Martín de Azpilcueta and Diego de Covarrubias y Leyva. ${ }^{46}$ At the very least, the emphasis on Grotius's ancient sources should not come at the price of 'editing out the mediating role of medieval jurisprudence and theology', as Randall Lesaffer has rightly suggested. ${ }^{47}$ Even at the level of major points of theological doctrine, to which Grotius attached a lot of importance, evidence is mounting that Arminian Calvinists, to whom Grotius belonged, heavily drew on Jesuit soteriology. ${ }^{48}$

On a final note, it is worth emphasizing that, compared to early-modern theologians and jurists influenced by the School of Salamanca, Grotius lived in a different context. Contrasting Grotius and his fellow country-man Lessius is telling in this respect. As a young man, Grotius defended the imperialist policies of the young Dutch Republic against overseas dominance by the Spanish and the Portuguese. Around the same time, Lessius was at the forefront of restoring Catholic life in the Habsburg Netherlands. While Grotius was negotiating the salvation of European states with diplomats in Paris, Lessius was teaching students in Louvain how to promote the salvation of souls. While Grotius indulged in poetry, Lessius prayed. Born in places a mere sixty miles apart from each other, the Sitz im Leben of their professional activities was different. Granted, they did share the commitment to create a legal order based on mutual trust and the solidity of contractual promises in order to stimulate trade beyond confessional divisions. Yet, ultimately, Grotius and Lessius did not live in the same socio-cultural environment. Juan de Lugo - the Jesuit Cardinal and author of a treatise On Justice and Right that closely followed Lessius's model discarded attempts, initiated in the early 1640 s by Cardinal Francesco Barberini, to convert Grotius to Roman Catholicism. In Lugo's view, the Swedish ambassador simply was not 'a good Catholic' ('non satis catholice'). ${ }^{49}$ Lugo feared that Grotius's tolerant irenicism came down to atheist pragmatism in disguise. But then, a good two decades earlier, Grotius's tolerant attitude had also instilled fear among authorities in the Dutch Republic. Maurice of Nassau,

\footnotetext{
46 Decock, Theologians and Contract Law, pp. 40-42.

47 R. Lesaffer, 'On Roman Ethics, Rhetoric and Law in Grotius', Journal of the History of International Law 10 (2008), 343-47, at pp. 346-47. Incidentally, Cicero, Seneca and Boethius were common sources in the works of Thomas Aquinas and his followers.

48 R.A. Muller, 'Arminius' “Conference" with Junius and the Protestant Reception of Molina's Concordia', in: Beyond Dordt and De Auxiliis. The Dynamics of Protestant and Catholic Soteriology in the Sixteenth and Seventeenth Centuries, ed. by J.J. Ballor, M. Gaetano and D. Sytsma (Leiden/Boston: Brill, 2020), pp. 103-126.

Nellen, Hugo Grotius: A Lifelong Struggle for Peace in Church and State, p. 649.
} 
the Stadtholder, did not consider Grotius 'a good Calvinist'. He was imprisoned by orthodox Calvinist compatriots and, practically speaking, condemned to a life in exile. But then, even Queen Christine of Sweden did not prolong his ambassadorship. With a versatile mind like his, Grotius was always going to remain suigeneris. 